\title{
THE CONTROL OF THE MILK SUPPLY IN AMERICAN CITIES.*
}

By C. H. TATTERSALL, D.P.H., \&c., Medical Officer of Health of Salford.

$\mathrm{T}^{\mathrm{H}}$ HE control of the milk supply is practically dependent on one fact, i.e., the Board of Health have discretionary powers in giving "permits" for the sale of milk in the city. These "permits" are renewable annually, and can be cancelled at any time by the Board, from whose decision there is no appeal.

It is obvious that this places the whole milk trade in the hands of the city authorities, and the great improvement of American methods over our own for procuring pure clean milk is mainly due to this somewhat arbitrary power.

The milk supply of the large cities is obtained from a very large area-milk being brought as much as 400 miles to New York, and 200 miles to Boston.

In America, as with us, the control of the farmer by the country authorities leaves very much to be desired, and consequently inspection of the farms supplying the city is carried out by the city veterinary inspectors, who have no legal standing outside the city limits; but, if a farmer refuses to allow inspection, the dairyman receiving his milk is notified that no further milk must be admitted to the city from that farm, and thus indirect pressure is brought to bear which is found to be speedily efficacious. If the farm is dirty, as, I am informed, it usually is, the farmer is warned, and if improvement does not take place, his farm is "put out of business" so far as the city's milk supply is concerned.

The various milk dealers have creameries in different parts, where the milk is received and at once stored in cans surrounded by ice, and it is shipped to the city in railway refrigerator trucks, specially built. I travelled about 120 miles and visited a number of farms, some of which were everything that could be desired, and others much like our own. The smaller farms seemed to be distinctly inferior to our Cheshire farms, and more like the small farms in Derbyshire, but there was evidence that much good work was being done to bring the standard of cleanliness to a satisfactory level.

Three farms I visited had excellent cow barns, one holding 100 cattle in one barn, and another nearly 200 in two barns, and the third

* From a Special Report on a recent visit to the United States. 
about 100 in two barns. The cattle were of various breeds, but there were some Jerseys in each herd, and one herd was entirely of pedigree Jerseys. These three farms obtained a special price for their milk. Whereas the ordinary milk is retailed from 5 to 6 cents per quart, these farms obtained 10 to 15 cents; but it was stated that in America, as here, the public did not appear prepared, even the educated public, to pay a reasonable price for a specially first-class article.

In these farms the cows were cleaned before milking, the teats, and the hands of the milkers (who wore quite clean white overalls) were washed. The milk was at once cooled, sieved, bottled, and packed in ice for transport. The bulk of the milk is sold in open cans as with us, but a certain amount is sold in bottles (New York, 20 per cent). Most of this bottled milk is bottled by the dairymen in the cities, but some is sent direct from the dairy as described. On arrival at the city, the milk trains are met by inspectors, who also inspect the milk shops and milk in the course of delivery. In Philadelphia and New York, if the milk has a temperature of over $55^{\circ} \mathrm{F}$. it is at once destroyed without further question, and no compensation is given.

In Philadelphia, the inspectors have a rough and ready way of testing milk, and if it shows signs of serious adulteration it is sampled and destroyed. In any event a large number of samples are taken daily and submitted to the analyst. A standard of 3 per cent fat and 12.5 or 13 of total solids is insisted upon, and failure to reach this standard entails prosecution, as with us.

A certain proportion of these samples are examined bacteriologically. In Philadelphia, where I saw this work carried out, twenty samples are examined daily for the presence of macroscopic dirt, streptococci, pus cells, and Bacilli subtilis, and if three successive samples from one milk are found wrong (the farmer being warned each time), the milk is refused admittance to the city until the farmer can satisfy the Board of Health that he has put everything right.

I was much impressed by the importance of our commencing to sample and examine milk bacteriologically, for although there may be no immediate prospect of satisfactory legislation, I am sure much might be done to obtain a purer supply, as I feel certain a great deal of help could be obtained from the milk dealers, who in the main are, I believe, most anxious to improve the quality of milk in this respect.

The measure already decided upon by the Committee to obtain Parliamentary powers for the control of licences will prove most valuable, and is very urgently needed. 